\title{
TERRITORIOS DE LO EXÓTICO EN LAS LETRAS ESPAÑOLAS DEL SIGLO XVIII
}

\author{
Francisco LAFARGA \\ Universidad Pompeu Fabra
}

Antes de entrar en materia resultará útil referirse a las definiciones contenidas en distintos diccionarios.

El de la Real Academia española dice en exótico: "1. Extranjero, peregrino, especialmente si procede de un país lejano. /2. Extraño, chocante, extravagante". En el Diccionario ideológico de Julio Casares puede leerse en la misma voz: "Extranjero, peregrino, de origen extraño y aún no aclimatado o admitido en el país de importación". La voz exotismo no ha sido admitida por la Academia hasta fecha reciente, e incorporada en la última edición (1992) del diccionario con estas definiciones: "1. Cualidad de exótico. / 2. Tendencia a asimilar formas y estilos artísticos de un país o cultura distintos de los propios". Anteriormente los sustantivos admitidos eran exotiquez y exoticidad. María Moliner recoge en exótico: "Se aplica a lo que procede de un país extranjero. También a lo que resulta extraño y tiene aspecto de extranjero".

Estas definiciones introducen matices no exentos de consecuencias: estamos en el terreno de los nacionalismos, de las literaturas nacionales, en el de los escritores no aclimatados o mal admitidos, en el de los marginales. Con todo, tomada al pie de la letra, alguna definición podría no ser de aplicación a lo literario, cuando de escritura o literatura exótica se trata, ya que en ella lo extraño o extranjero no puede decirse que no esté aclimatado, pues no sólo está aceptado dentro de la obra, sino que forma parte consustancial de la misma. Ahora bien, tal afirmación es válida dentro de la propia obra, ya sea literaria o

1. Algunos diccionarios franceses (Robert, Larousse), ampliando el campo, establecen el límite en el ámbito de la cultura occidental. 
artística, aunque el valor "extraño" continúa presente y activo para lo que está fuera de ella, para el lector o el observador.

Lo exótico puede concebirse también como un secreto de toda literatura, como fuente de misterio, con capacidad de producir el interés del lector y mantener la tensión de la lectura. Por eso, la representación del extranjero o de lo extranjero en la literatura, en ocasiones la instituye y constituye como tal (véase Fernández Cardo 1989).

La concepción del exotismo ha tenido distintas direcciones y presenta diversos matices.

En algunos autores consiste fundamentalmente en el deseo de describir un país distinto del propio, ya sea basándose en elementos reales, vividos por el propio escritor o debidamente documentados, o ya utilizando nociones convencionales, nutridas de estereotipos e ideas preconcebidas.

En otros casos lo que mueve al escritor es el deseo de aventura, el ansia de huida o la búsqueda de la felicidad.

También puede estar animado por un intento de conocimiento, de descubrimiento de nuevos paisajes, de modos de vivir distintos, en suma, por un nuevo humanismo.

Visto desde un prisma estrictamente literario, el exotismo es un procedimiento que se ha utilizado como ornato por el agradable colorido que aporta o por la variedad que produce; su presencia en este sentido ha sido más notable a partir del Romanticismo.

Se ha utilizado asimismo para la demostración de una tesis o como tapadera para la crítica social y filosófica. Tal uso, como es sabido, tuvo sus mejores expresiones durante el siglo XVIII.

Finalmente, se da también un exotismo exacto, realista. Es el de los viajeros cuando son escritores de talento: Chateaubriand, Flaubert, Loti. Hay en estos autores una búsqueda de sensaciones más intensas, de emociones más fuertes que las que podían experimentar en sus círculos habituales. Con todo, como escritores que son llevan a cabo una selección de lo que ven, una elaboración "literaria" de sus experiencias, con lo cual se distinguen de los autores de relatos de viajes que son simples viajeros.

Tal vez sea difícil, si no imposible, hablar de literatura exótica como expresión caracterizada, definida de una actitud del escritor ante un objeto determinado. Es más cómodo, y más acorde también con la realidad, referirse a presencias de lo exótico en la literatura o a los "territorios" de lo exótico. Además, interviene aquí la cuestión de los límites que se quieran dar a la "literatura" o a lo "literario". Conviene saber si, aparte de los grandes géneros tradicionales, debemos o podemos considerar literatura los libros de viajes o la 
prensa, por ejemplo. A nadie se le oculta que el exotismo tiene en el relato de viaje su lugar natural, aunque el autor (no necesariamente escritor) no se proponga incidir en una vena exótica.

Hay otros límites a tener en cuenta: la propia frontera de lo exótico, es decir, saber dónde empieza lo "extranjero", lo "peregrino" y dónde termina lo nacional o lo habitual. Creo que lo exótico es, por naturaleza, subjetivo y cambiante; y parece que no hay que adoptar una interpretación tajante y restrictiva, que consideraría exótico todo lo extranjero. Porque, además, esa interpretación lleva de la mano otra no poco ardua: ¿qué es lo nacional? La respuesta a tal interrogante debería barajar aspectos geográficos, lingüísticos, raciales, políticos. Aun a riesgo de limitar el campo, o tal vez para delimitarlo, sería partidario de considerar exótico aquello que no pertenece al ámbito cultural amplio del país en que se analiza el fenómeno: en este caso, lo que se halla fuera del ámbito europeo. Pero, se me dirá: ¿qué era Europa en el siglo XVIII? ¿De qué Europa se trata?

Por otro lado, el concepto o, mejor dicho, el grado de exotismo puede variar de una época a otra. Es cierto que las facilidades actuales para viajar, unidas a una mayor difusión de todo lo extranjero, hacen que cada vez resulte más difícil sorprender a un público medianamente culto. Ya a mediados del siglo XIX, el escritor francés Xavier Marmier se lamentaba de la pérdida de prestigio de los viajeros:

Adiós a los vagos prestigios con que uno se cubría al regreso de lejanas regiones. Ya no quedan regiones lejanas. Se va usted a pasar varios meses al campo. Regresa a París al mismo tiempo que la gente de mundo... Durante el poco tiempo que Vd. los ha dejado, éste ha cruzado el Sahara, aquél ha ido a ver las ruinas de Tebas o los palacios de Granada o las orillas del Neva. El que sólo ha ido a Alemania permanece humildemente a un lado y no se atreve a decir ni una palabra de una excursión tan cortita. ¿Adónde habrá que ir, Dios mío, para poder decir que se viene de lejos? ¿No se va en veinte días a Suez a Bombay, en tres semanas de Londres a Nueva York, y con los barcos transatlánticos no se irá también en pocas semanas de Burdeos a México? De México al cabo de Hornos no hay más que un paso. Con una hélice y varias toneladas de carbón se soluciona el asunto... Sin duda alguna nuestro globo se ha quedado demasiado pequeño... pronto ya no habrá viajes extraordinarios ${ }^{2}$.

2. “Adieu les vagues prestiges dont on était paré au retour de régions lointaines. Il n'y a plus de régions lointaines. Vous vous en allez passer quelques mois à la campagne. Vous rentrez à Paris au temps où les gens du monde y reviennent... pendant la peu de temps que vous les avez quittés, celui-ci a traversé le Sahara, cet autre a été voir les ruines de Thèbes ou les palais de Grenade, ou les rives de la Néva. Celui qui n'a été qu'en Allemagne se tient humblement à l'écart et n'ose dire un mot d'une si petite excursion. De quel côté se tourner, grand Dieu! pour pouvoir dire qu'on vient de loin? Ne va-t-on pas en vingt jours de Suez à Bombay, en trois semaines de Londres à New York, et avec les bateaux transatlantiques n'ira-t-on pas de même en quelques semaines de Bordeaux au Mexique? Du Mexique au cap Horn il n'y a qu'un pas. Une hélice et quelques tonnes de charbon en feront l'affaire... Décidément notre globe est trop petit... bientôt il n'y aura plus de voyages extraordinaires": X. Marmier, Du Rhin au Nil, París, 1846, vol. II, págs. 2-3; cit. por Jourda, pág. 22 nota 1. 
Cabría, finalmente, plantear otro tema: el de la presencia de lo exótico en las distintas épocas o períodos literarios. ¿Existen épocas privilegiadas, en las que el grado o la carga de exotismo, si podemos hablar en términos cuantitativos, es mayor que en otras? La respuesta es, pues así lo demuestra la historia, afirmativa. El siglo XIX y, en particular, el Romanticismo, por distintas razones (gusto por el color local, ansia de huida), aparecen más impregnados de exotismo que cualquier otra época. Pero eso no significa que en épocas anteriores lo exótico estuviera totalmente ausente de la literatura. No parece llevar mucha razón Gérard de Nerval cuando escribe en su Voyage en Orient, de 1851:

Ha habido tiempos en los cuales no han existido impresiones de viaje [...]. Es posible, pues, viajar sin mirar, o bien mirar sin ver. Fue preciso que Bernardin de Saint-Pierre viera los extraños paisajes de América y de las Indias para crear, de algún modo, el color local [...]. Pues bien, el propio Bernardin de Saint-Pierre sólo encuentra admiración para los árboles y las flores; vio Italia, Flandes y Alemania sin notar más que ciudades bien o mal trazadas ${ }^{3}$.

Ignoraba Nerval los relatos medievales, de los que bastará recordar El millón de Marco Polo, así como los numerosos textos redactados en el siglo XVI, época de descubrimientos, de apertura de horizontes, de choque de razas y culturas. En este contexto, España, tanto por su itinerario histórico como por su situación geográfica, se hallaba en una posición bastante peculiar respecto del resto de los países de su entorno cultural.

Sin tender a considerar aquello de que "África empieza en los Pirineos" (pues de todos es sabido que empieza al otro lado del estrecho de Gibraltar), lo cierto es que la península se halla en una situación privilegiada para los contactos entre Europa y los países musulmanes del norte de África. Por otra parte, no está de más recordar los siete siglos de permanencia de árabes o norteafricanos en España, que dejaron innumerables huellas en la lengua, la toponimia, la literatura y el arte, y no sólo en la corona de Castilla.

Por ello, al tratar de exotismo, y sobre todo de exotismo oriental, parece como si en el caso de España los límites fueran todavía más imprecisos. No quiero decir que en la España del siglo XVIII se tuviera perfectamente asumido o asimilado lo oriental o parte de ello, grosso modo de Arabia para acá: D. Pelayo, las Navas de Tolosa e incluso la toma de Granada quedaban ya bastante lejos. Sin embargo, los musulmanes, los moros, formaban parte de la historia de España, de las luchas por la expansión hacia el sur de los nacientes reinos

3. "Il y a eu des temps où l'impression de voyage n'existait pas. [...] Il est donc possible qu'on voyage sans regarder, ou bien qu'on regarde sans voir. Il a fallu que Bernardin de SaintPierre vit les étranges paysages de l'Amérique et des Indes pour créer en quelque sorte la couleur locale. [...] Eh bien, Bernardin de Saint-Pierre lui-même ne trouve d'admiration que pour les arbres et pour les fleurs; il a vu 1'Italie et la Flandre et 1'Allemagne sans y remarquer autre chose que des villes bien ou mal bâties": G. de Nerval, Voyage en Orient, París, Calmann Lévy, 1883, t. II, págs. 438-440, cit. por Jourda 1938, pág. 17. 
cristianos, y también de la simbiosis cultural que se fue gestando durante aquellos siglos.

Cabría, con todo, establecer una diferenciación entre el musulmán que forma parte de la historia de España o, si se quiere, de Al-Andalus y el otro, el del norte de África, de Egipto o de Arabia. Todos pueden ser considerados desde el mismo prisma, pero el grado de exotismo, de extrañeza es distinto.

Otro tanto podría decirse de lo americano, lo hispanoamericano. Quedaba ya lejos 1492, con el choque de dos culturas, de dos mundos, el acceso a lo desconocido, a lo imprevisto. Se habían multiplicado durante los siglos XVI y XVII los testimonios de descubridores, conquistadores, colonizadores $\mathrm{O}$ evangelizadores. Viajeros y cronistas primero, literatos más tarde, habían integrado lo americano al acervo común.

Parece que en el siglo XVIII los españoles viajaron menos que otros europeos, y pocos fueron los viajeros que dejaron constancia escrita de sus experiencias. Eso hace que la literatura de viajes sea relativamente limitada: cierto es que hay textos por estudiar, incluso por descubrir. De los conocidos, la mayoría tuvieron como meta algún país europeo, Francia sobre todo, aunque también Inglaterra e Italia. Los que se dirigieron al continente americano tuvieron normalmente por objetivo alguna misión científica, aunque los relatos de los mismos contienen también indicaciones correspondientes a las gentes y a las culturas.

De la expedición que Jorge Juan y Antonio de Ulloa, en compañía del francés Godin, realizaron entre 1735 y 1744 al Perú para medir un arco de meridiano terrestre y conocer con exactitud la forma de la Tierra ha quedado una Relación histórica del viaje a la América meridional (Madrid, A. Marín, 1748). Años más tarde, en 1767, el mismo Jorge Juan realizó como embajador un viaje a Marruecos, aunque el diario del mismo no se publicó hasta principios del siglo XIX (Madrid, s.i., 1816). Casi diez años (1777-1787) estuvieron investigando en el Perú los botánicos José Pavón e Hipólito Ruiz: el resultado de sus esfuerzos fue, entre otras obras, una monumental Flora peruviana et chilensis (Madrid, G. de Sancha, 1798-1802, 3 vols.). Con todo, la más famosa de las expediciones españolas fue el viaje alrededor del mundo realizado entre 1789 y 1794 por Alejandro Malaspina y José Bustamante, con visitas a todas las colonias españolas de Ultramar. No pasaron por Tahití, isla que durante cuatro años (1772-1776) fue llamada por los españoles Isla de Amat, en homenaje al virrey del Perú que ordenó distintas expediciones, logrando incluso que los jefes nativos reconocieran por soberano a Carlos III. Los diarios de a bordo y las descripciones de los lugares visitados se publicaron a finales del siglo XIX con el título Viaje político-científico alrededor del mundo (Madrid, Vda. e hijos de Abienzo, 1885) ${ }^{4}$.

4. Sobre estas expediciones puede consultarse AA.VV. 1989 (obra rica en información e iconografía), así como la bibliografía crítica recogida por Aguilar Piñal 1988, págs. 282-286. 
Los Viajes de Ali Bey por África y Asia merecen un momento de atención. Se trata de un caso bastante particular, pues implica una transformación del individuo, un cambio de personalidad. Domingo Badía, empleado del monopolio de Tabacos, arabista autodidacta, profundo conocedor del mundo musulmán, emprendió en 1803 un largo viaje (financiado al parecer por el príncipe de la Paz) que, durante cinco años, iba a llevarle de Madrid a La Meca, pasando por Marruecos, Trípoli, Chipre; Egipto, Palestina, Siria y Turquía. Para tal periplo, después de haberse hecho circuncidar, asumió la personalidad del príncipe Alí Bey el Abasí, hijo de Otmán. Como dice en la introducción:

Después de haber empleado tantos años por los estados cristianos estudiando en sus escuelas las ciencias de la Naturaleza y las artes útiles al hombre en el estado de sociedad, sea cual fuese el culto o religión de su corazón, tomé en fin la resolución de viajar por los países musulmanes, y cumpliendo al mismo tiempo con el sagrado deber de la peregrinación a La Meca, observar las costumbres, usos y naturaleza de las tierras que se hallasen al paso, a fin de no hacer inútiles las fatigas de tan larga travesía, y sí provechosas a mis conciudadanos en el país que escoja finalmente por patria (Véase Badía 1986, I, págs. 15-16).

Habiendo regresado a España tras su viaje, sirvió a José Bonaparte, por lo que hubo de abandonar el país con los franceses. Y su libro se publicó primero en París y en francés (1814), y aun en inglés e italiano antes de ver la luz en español $(1826)^{5}$. La riqueza de su relato es impresionante, pues a las detalladas descripciones se unen mapas y dibujos de su propia mano sobre monumentos visitados o curiosidades vividas. Para Juan Goytisolo, en el prólogo a una edición reciente de los Viajes:

La variedad y soltura de la narración, el acopio de datos etnológicos, científicos y geográficos, el rigor y exactitud con que describe las ceremonias sagradas, lo estupendo de algunos episodios y aventuras le otorgan un puesto privilegiado y a veces único en esta pléyade de aventureros, exploradores, misioneros y agentes coloniales que [...] adopta ese peculiar sistema de l'éducation par le voyage que tanta aceptación tuvo entre los escritores románticos, mezclando los móviles políticos y profesionales con una querencia personal a los modos de vida árabes y una íntima fascinación por el Islam (Véase Badía 1986, I, pág. XI).

Otro aspecto no desdeñable hay en el texto: una postura de rechazo de la sociedad mercantilista o industrial y la busca de una autenticidad primitiva.

El interés por los relatos de viajes hizo sin duda que se publicaran antiguos periplos, como el primer viaje alrededor del mundo de Magallanes y Elcano, dado a luz en 1769 por el médico y botánico Casimiro Gómez Ortega. El jurista Llaguno y Amírola publicó también la Historia del gran Tamorlán (Madrid, A. de Sancha, 1782), con el relato de la embajada enviada por Enrique III de Castilla.

5. Véase para las ediciones, así como para los estudios sobre esta obra, Aguilar Piñal 1981, I, págs. 483-484. 
Otros relatos de viajes o descripciones de lugares recónditos procedían de otras lenguas. Así, el Imperio de Osmán, comúnmente llamado Otomano (1785), traducido del alemán Busching, a través del francés; o el Viaje al interior de la China y Tartaria hecho por el embajador del rey de Inglaterra a finales de siglo ${ }^{6}$. Es original, descripción de la embajada que Carlos III envió al sultán con numerosos regalos, el Viaje a Constantinopla en el año 1784 de José Moreno (Madrid, Imprenta Real, 1790), que cuenta, según anuncio aparecido en la Gaceta, "los usos más notables del país, las costumbres de sus gentes, el sistema de su gobierno, su constitución política y militar", e incluye una veintena de grabados. También original es la Idea del imperio otomano (Madrid, Sancha, 1793) que el capitán de fragata José Solano, hijo del marqués del Socorro, redactó en su viaje a Constantinopla de 1787.

Los periódicos de la época ofrecían noticias y comentarios sobre viajes o descripciones de países lejanos. Una de las primeras menciones que he encontrado aparece en el Diario curioso, histórico, comercial, público y económico de Barcelona de 3 de Abril de 1762: se trata de la descripción de la "mezquita mayor del Gran Turco". El Correo de Madrid (1786-1791)7 insertó también varias descripciones de lugares y artículos históricos: sobre Tamerlán o Tamorlán, emperador mogol, dentro de una serie en la que figuraban Filipo de Macedonia, Mecenas, Tomás Moro o el Tasso, por ejemplo; sobre el heroísmo de Murad, gran visir del sultán Ahmet I. Sin embargo, predominan en este periódico los cuentos y apólogos orientales (El envidioso, El juez prudente, Hamet y Raschid, Medio de resucitar los muertos, La reina de Goa, El testamento); en este sentido, cabe decir que el Diario de Madrid fue uno de los primeros en dar ejemplo con la publicación, entre Junio y Julio de 1759, de la traducción o, mejor dicho, de la adaptación de Zadig, el célebre cuento volteriano (véase Guinard, 1958).

En otros casos (y volviendo al Correo), el decorado oriental sirve de excusa a la sátira, como la burlesca Idea de un escrito en forma de diccionario propuesto por un abate del Japón, o la Carta de un viajante chino a un amigo suyo de Pekín, sobre la injusticia. Algunos textos tienen asimismo una dimensión crítica, como la Noticia de los harenes y serrallos y el Paralelo de la suerte feliz o desgraciada entre las mujeres asiáticas y africanas y las europeas.

Resueltamente cosmopolita, el Espíritu de los mejores diarios literarios que se publican en la Europa (1787-1791) no podía dejar de insertar artículos o comentarios referidos al Oriente, pues éste ocupaba un lugar privilegiado en los periódicos extranjeros (véase Varela 1966). Los textos suelen ser más técnicos que los que aparecían en el Correo. Así, pudieron leerse en sus páginas un resumen de la religión y de la moral de los indios (Bhaguat Geeta o Diálogo de Kroesha y de Arjou), una Descripción de una fiesta religiosa en la costa de

6. Se publicó en Madrid, en 1798, traducido por María Josefa Luzuriaga.

7. Véase el vaciado del periódico en Iglesias y Mañá 1968. 
Malabar, una Noticia de la isla de Ceilán, reseñas de varios relatos de viajes ingleses y franceses, así como del libro de J.B. Toderini sobre la literatura de los turcos. Pareció también interesante relatar la embajada del príncipe de Cochinchina a la corte de Luis XVI. No siempre la mirada se dirigía al Este: prueba de ello son unas Reflexiones sobre los hotentotes. Son escasas las obras que pueden considerarse de creación: alguna fábula y varias anécdotas, como la que recoge la orden del emperador chino Kim Long, que mandaba premiar a todos los ancianos respetables.

Anecdótica, aunque vivida por muchos madrileños, fue la llegada a la corte de una embajada del sultán, que traía originales regalos para Carlos III:

Vienen para S.M. doce dromedarios, que es una especie de camello salvo que tiene dos gibas, cargados cada uno con arcas de cedro [...] en que vienen muchas piezas de estrofa, paños, especies y aromas de Asia. Un hermosísimo elefante asiático de 38 años, tan diestro y bien disciplinado, que al son del laúd hace en dos pies diferentes mudanzas de baile tudesco. Para cuidar de este elefante vienen dos lacayos o mozos de caballerizas. Estos mozos vienen con sus mujeres e hijos, que son todos bellísimas criaturas. Conducen asimismo en dos grandes jaulas dos grandes caimanes nilóticos, fieras jamás vistas en Europa, las cuales, aunque son por naturaleza muy feroces, estos están domesticados y se dejan manosear y meter el brazo en la boca $[\ldots]$. Asimismo envía el sultán doce caballos de la Morea con todos sus jaeces bordados primorosamente en oro y plata, y con cada uno viene de regalo un jenízaro, que es una especie de soldado valientísimo [...] vestido riquísimamente a la turca, con sus cimitarras, fusiles, pistolas y demás armas con guarniciones de oro labradas en Persia. Vienen también de regalo para S.M. seis doncellas georgianas hermosísimas, muy blancas y fornidas, vestidas a la persa [...]. Para custodia y resguardo de estas hermosas doncellas vienen doce eunucos esclavos, que también vienen de regalo. Poseen el arte de la música y cantan maravillosamente con voz atiplada ${ }^{8}$.

Parece que lo que más llamó la atención popular fue el elefante, pues poco tiempo después Ramón de la Cruz hizo representar un divertido sainete, El elefante fingido, en el que, precedidos por la fama del animal, unos gitanos simulan uno de trapo para conseguir unas monedas en los pueblos que visitan ${ }^{9}$. En los periódicos de los últimos meses de dicho año se anunció la venta de folletos y grabados que representaban elefantes ${ }^{10}$, y el fabulista Iriarte escribió en Enero de 1774 una epístola a su amigo Cadalso en la que se hacía eco de la visita:

8. Texto citado por Bravo Morata 1972, págs. 79-81, sin indicar la fuente.

9. Permaneció inédito hasta su publicación en Cruz 1915, II, págs. 323b-329b.

10. Así: Descripción del elefante, con su alimento, costumbres, enemigos e instinto; y explicación del uso que se hace de los elefantes, modo de cazarlos y utilidades de sus colmillos en la Medicina y en las Artes: con la estampa y noticias circunstanciadas del que se ha remitido de Manila para el Rey nuestro señor (anuncio de la Gaceta de Madrid de 7 de Septiembre de 1779, n. 36, pág. 320), - la Estampa de marca mayor que representa el elefante, copiado del natural, y su esqueleto; el rinoceronte o abada, y la historia natural de uno y otro, con noticia del elefante y rinoceronte que hubo en esta corte en tiempo del rey D. Felipe II (anuncio de la Gaceta de 7 de Diciembre del mismo año, n. 49, pág. 428). Nótese la utilización comercial de acontecimientos anteriores. 


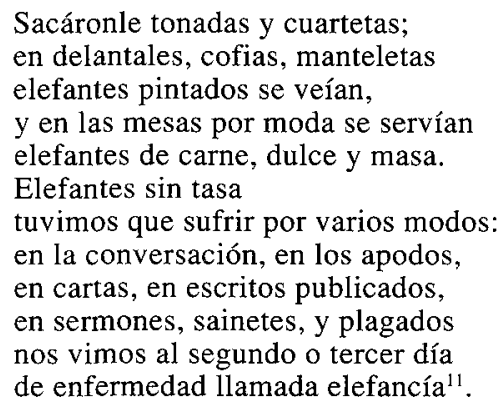

La literatura de creación adoptará, también en España, ambientes o personajes exóticos para la expresión de una sensualidad o de una crítica social.

Parte de la literatura narrativa procedía del extranjero, usualmente a través de textos franceses. En el catálogo establecido por Fernández Montesinos podemos hallar títulos representativos, algunos de ellos de aparición tardía en castellano: Las mil y una noches de Galland (París, 1838), las Cartas persas de Montesquieu por Marchena (Nîmes, 1818), Gonzalo de Córdoba o La conquista de Granada de Florian por Juan López de Peñalver (Madrid, 1794), Viajes de Antenor por Grecia y Asia de Lantier (Madrid, 1802, 3 vols.), Pablo y Virginia de Bernardin de Saint-Pierre por José Miguel de Alea (Madrid, 1798) y El inglés en la India o La cabaña indiana del mismo autor (Salamanca, 1803), los Viajes del capitán Lemuel Gulliver a diversos países remotos de J. Swift por Ramón M. Espartel (Madrid, 1793, 3 vols.) $)^{12}$, a los que habría que añadir las Cartas de una peruana de Mme de Graffigny, traducidas por Marta Romero Masegosa (Valladolid, 1792).

El carácter crítico o/y erótico de algunas obras no pasó inadvertido a la Inquisición, que prohibió, entre otros, los siguientes relatos: Lettres persanes, Lettres chinoises, Lettres juives, Lettres d'une Péruvienne, Le sopha, Angola, Robinson Crusoe, Les mille et une heures (véase Defourneaux 1973).

El Consejo de Castilla tampoco concedió la necesaria licencia de impresión a Ramón Bonifaz para editar su Viaje de Roberto Montgolfier al país de las antípodas de la Nueva Zelanda. Vieron la luz, sin embargo, algunos otros textos más o menos utópicos, como los Viajes de Enrique Wanton a las tierras incógnitas australes y al país de las monas (Alcalá-Madrid, 1769-1778): de los cuatro volúmenes de que constaba, los dos primeros eran traducidos de Zaccaria Seriman, mientras que los dos restantes eran originales del traductor, Gutierre Joaquín Vaca de Guzmán. Siguiendo el ya conocido expediente del naufragio y

11. Cit. por Cotarelo 1897, págs. 133-134; compuso también Iriarte un soneto y dos décimas al mismo asunto, publicados en AA.VV. 1952, 2, págs. 51 y 60.

12. Todas estas traducciones aparecen mencionadas en Fernández Montesinos 1966. 
del arribo a una isla, se suceden en la obra lances y aventuras, acompañadas de la crítica de la sociedad (véase Escobar y Percival 1984).

Más plenamente utópico resulta el breve relato sobre las costumbres de un pueblo imaginario, los Ayparcontes, inserto en tres "discursos" (el 61, el 63 y el 75) de El Censor de 1783: utopía religiosa que tiene por finalidad realizar una profunda crítica del clero, describiendo la sociedad de un país desconocido situado, una vez más, en tierras australes, de una isla a la que, una vez más, llega un viajero tras naufragar.

Vieron la luz también en las páginas de los periódicos dos textos novelescos en forma de cartas, pertenecientes a dos de los mejores autores del siglo: Cadalso y Meléndez Valdés.

Las Cartas marruecas estaban ya listas en 1774 y el manuscrito presentado al Consejo de Castilla para su aprobación: a pesar de obtenerla, su autor no las publicó en su día y, de hecho, murió sin ver cumplida la empresa. Aparecieron entre Febrero y Julio de 1789 en las páginas del Correo de Madrid, y cuatro años más tarde fueron publicadas formando volumen.

Respondían a un esquema de cierto prestigio en Europa: se ha hablado ya tanto de sus relaciones formales y temáticas con las Cartas persas de Montesquieu que es superfluo evocarlas aquí ${ }^{13}$. Con todo, hay un punto que me interesaría poner de relieve: la conciencia que tenía Cadalso de que el procedimiento que pensaba utilizar no era original y su deseo de dar visos de verosimilitud a su texto. "Sería increíble el título de cartas persianas, turcas o chinescas, escritas desde este lado de los Pirineos", dice en la introducción, y tenía razón, pues las relaciones entre España y aquellos países eran prácticamente nulas.

Muy distinto era el caso de Marruecos, vecino de España, con quien se intentaba mantener buenas relaciones. Había causado sensación, en 1766, la visita a España de Sidi Hamet al Ghazzali, embajador del emperador marroquí: folletos, grabados, noticias en la prensa nos informan del fasto de su séquito y de los honores con que fue recibido en las distintas ciudades que visitó. El protagonista de las Cartas marruecas es precisamente Gazel, miembro del séquito de un embajador marroquí que solicita quedarse en España para conocer mejor el país ${ }^{14}$.

Menos célebres que las marruecas son las Cartas turcas (o Cartas de Ibrahim) de Meléndez Valdés, que tienen su origen precisamente en un deseo de continuar y completar las de su amigo Cadalso, ya fallecido. Así se desprende de la solicitud de impresión remitida al Consejo de Castilla: aunque éste no puso reparos a la publicación, las cartas no se imprimieron nunca en forma de libro

13. Véanse, entre otros, Bremer 1971, Cotton 1931, Huges 1969, y Laborde 1952.

14. Véase el prólogo de Cadalso 1966. 
y su original desapareció. Sólo vieron la luz las dos primeras, en sendos periódicos: la carta de Ibrahim en Madrid a su esposa Fátima en Estambul en el Diario de Madrid de 10 de Diciembre de 1787, y la respuesta de Fátima en el Correo de Madrid de 19 del mismo mes. Lo que en ellas se dirime es la cuestión de la distinta situación de la mujer en España y Turquía, la educación que debe recibir, la libertad de que puede o debe gozar. Esta idea había aparecido ya en las Cartas persas (que tienen un personaje "contado" de nombre Ibrahim), aunque no expresada de modo tan directo como aquí, en que Fátima sale en defensa de la autonomía de la mujer frente al hombre de modo general... aunque declarando su fidelidad y sumisión a Ibrahim. Algo, sin embargo, parece estar fraguándose en el lejano harén, bajo la aparente calma de unas esposas resignadas. Desgraciadamente, no podemos saber por ahora la continuación (véase Deacon 1981, que incluye el texto de las cartas).

El disfraz chino le sirvió a Juan Pablo Forner para lanzar una violenta sátira contra su enemigo Tomás de Iriarte, titulada Los gramáticos. Historia chinesca. La obra se redactó en el verano de 1782 y el autor pidió licencia para publicarla, pero le fue denegada por considerarla un libelo infamatorio, al parecer por presiones del propio Iriarte y de su hermano Bernardo, ambos muy influyentes en la Corte. Sea como fuere, el texto quedó inédito hasta 1970, año en que aparecieron dos ediciones ${ }^{15}$. John H.R. Polt, en el prólogo de la suya, resume así la obra:

El joven Chao-Kong, habiendo estudiado con los bonzos del Japón, vuelve a Pekín y es nombrado preceptor del hijo de un prócer. A pesar de su calidad de mero gramático, hace carrera; y después de bien establecido en la corte imperial trae a ella a dos sobrinos suyos. Uno de estos, Chu-su, recibe de su tío valiosas lecciones en el arte de parecer sabio sin serlo y de ser poeta sin ciencia y sin esfuerzos. El filósofo Kin-taiso trata de desengañar a Chusu, pero éste se deja llevar por su vanidad. En este momento un recién llegado a la corte publica un folleto en el cual llama asno a Chu-su. Éste quiere responderle, pero Kin-taiso le persuade a hacer un viaje a Europa. En Madrid llega a sus manos la relación de una controversia ocurrida entre dos literatos españoles, marcadamente parecida a cuanto le ocurriera en Pekín. Encuentra además una crítica devastadora de las obras de Tomás de Iriarte, a quien se había propuesto imitar. Con esto se da cuenta de su propia ignorancia, ligereza y vanidad, y se propone una radical enmienda (Forner 1970, ed. Polt. págs. 14-15).

La alegoría es bantante clara: Chao-kong es Juan de Iriarte, tío de Tomás, o sea Chu-su; el Japón es Francia y los bonzos son los jesuitas; Pekín es Madrid. El joven que increpa a Iriarte es Forner, cuyas ideas expresa también el filósofo Kin-taiso. La carga de crítica social que se oculta tras los disfraces chinos es mínima, y la parte del león se la lleva la sátira personal, a menudo

15. La de José Jurado, Madrid, Espasa-Calpe ("Clásicos Castellanos") y la de John H.R. Polt, Madrid, Castalia. 
violenta y que termina por cansar al lector precisamente por personalizada. Queda, con todo, la utilización de nombres y ambientes chinos, de algunos términos filosóficos o religiosos, tomados seguramente por Forner de la Enciclopedia, del Ensayo sobre las costumbres de Voltaire o del compendio del padre Du Halde. Se ha llamado la atención, y con razón, sobre el hecho de que Tomás de Iriarte hubiera traducido hacia 1770 la tragedia de Voltaire $E l$ huérfano de la China, y de que el filósofo francés, blanco de los ataques de Forner, hubiese elogiado la ciencia de los chinos:

La autoridad es tomada de un célebre cómputo de M. de Voltaire; y es que allá cuando no sabían escribir, escribieron los chinos unas terribles crónica que hacían subir la existencia de su nación mucho más arriba de la existencia del universo; y lo que es más, halló dicho Señor Filo-histori-critipoeti-físico-matemático que en aquel puntual y crudo tiempo eran ya los chinos estupendos astrónomos y acérrimos impresores ${ }^{16}$.

En los últimos años del siglo y primeros del XIX se publicaron distintos relatos en los que lo exótico tiene notable presencia. En la Colección de cuentos morales (Salamanca, Tójar, 1796), traducida por Francisco de Tójar, prolífico traductor, adaptador y editor, se halla Zimeo, original de Saint-Lambert, historia de la revuelta del protagonista, esclavo negro, contra los terratenientes blancos de Jamaica. La negritud, asociada a la sensibilidad, se halla también en una de las Nuevas novelas de Florian, traducidas por Gaspar de Zavala y Zamora en 1799: Sélico, "novela africana" que intenta mostrar que la virtud y la justicia se hallan incluso entre los pueblos considerados más bárbaros. En 1804 (Madrid, Vda. de López), seis años después de la muerte de su autor, vieron la luz los dos volúmenes de Mis pasatiempos, conjunto de relatos de Cándido María Trigueros, subtitulado "Almacén de fruslerías agradables". En él pueden hallarse distintos relatos o cuentos de ambiente árabe: La hija del visir de Garnat (la acción transcurre en Granada), El juez astuto, El paraíso de Shedad, El santón Hasan, El egipcio generoso. La moraleja que puede extraerse de todos ello es muy clara: la felicidad se consigue con la virtud (véase Álvarez Barrientos 1991 y Aguilar Piñal 1987, págs. 255-263).

Mayor envergadura tiene Oderay, novela traducida del francés (atribuida a Palissot de Beauvois) por Zavala y Zamora y publicada el mismo año de 1804 (Madrid, Fuentenebro y Cía.). Su largo subtítulo es todo un programa: Usos, trajes, ritos, costumbres y leyes de los habitantes de la América septentrional. Es la historia de un europeo ya adulto, adoptado por una tribu de indios, en la que se convierte en un guerrero más, cambiando incluso de nombre. Todo se lo debe a la india Oderay, que acaba enamorándose de él y siendo rechazada por el muchacho, que conserva el recuerdo de una amada que dejó en Europa. La

16. Forner 1970, ed. de Polt, pág. 93. En Candide de Voltaire, el preceptor Pangloss enseña la "métaphysico-théologo-cosmolonigologie". 
novela termina con el suicidio de Oderay. El relato, que contiene muchas noticias sobre las costumbres y creencias de los indios, aúna el exotismo americano con la idea del buen salvaje y cierta dosis de sentimentalismo ${ }^{17}$.

En cambio, la acción de El emprendedor o aventuras de un español en el Asia de Jerónimo Martín (Madrid, Vega y Cía., 1805) transcurre en Basora. El autor demuestra gran conocimiento de la cultura árabe, a la que presenta sin prejuicios civilizadores, otorgando a sus creencias y costumbres un valor y un grado de respetabilidad semejantes a las de España u otros países europeos. En la misma línea de reivindicación de la cultura árabe, en este caso a través de la cultura gitana, se halla La gitana o memorias egipcias, novela del periodista Pedro María Olivé publicada en 1817 formando parte de la Biblioteca universal de novelas, historias y cuentos, que él mismo dirigía (Madrid, L. Núñez). Es, al mismo tiempo, una afirmación del papel de la mujer en la sociedad... árabe, y occidental por transposición.

La presencia de lo exótico en el teatro venía avalada por una larga tradición en Francia y otros países cuando empiezan a darse en España tragedias y comedias nuevas, modernas y, en general, ajustadas a las reglas. La Zaira de Voltaire conoce su primera versión castellana en 1765, a la que seguirán otras hasta la más célebre de García de la Huerta en $1784^{18}$. Ramón de la Cruz tradujo en 1769 el Bayaceto de Pradon y poco más tarde ideó un sainete paródico (en realidad adaptación de una obrita francesa) que tituló Zara, seguramente en recuerdo de la tragedia de Voltaire, pero que no es parodia de ésta (véase Lafarga 1977). Por su parte, el duque de Aliaga compuso en 1797, para que fuera representada en el teatro particular del palacio de su padre, el duque de Híjar, una adaptación de la tragedia francesa Mahomet II o el fanatismo de la gloria (Madrid, B. Cano, 1797): en ella el sultán de Turquía, enamorado de Irene, esclava griega cristiana, debe enfrentarse a distintas presiones de sus consejeros y de los notables; como en la Raquel de García de la Huerta, la intrusa deberá perecer.

La primera tragedia oriental española fue, sin duda, El Viting de Cándido María Trigueros. Fue escrita en 1768 y se conserva en un manuscrito fechado en 1776, no llegando a ser publicada ni representada en teatros públicos (impresa, anónima, en Barcelona, P. Nadal, 1799). Según afirma su autor en una carta dedicatoria, "el hecho o acción de esta tragedia es sacado de una historieta italiana manuscrita, que se dice traducida del lenguaje chino y trata de la destrucción de la familia o dinastía Ming por los tártaros, hoy dominantes

17. Véase Carnero 1988, págs. 23-29. Hay ed. moderna de Oderay por G. Carnero (Barcelona, Sirmio/Universidad de Alicante, 1992).

18. Sobre estas versiones puede verse Lafarga 1982, págs. 164-174, ampliado en la versión francesa, Lafarga 1989, págs. 113-122. 
en China". El nudo de la pieza es el dilema (que acabará en muerte) entre el deber y el amor en que se debate el protagonista, entre la fidelidad debida a su padre el emperador y a su patria, y el amor que siente por la princesa tártara Taicún. En las acotaciones se realzan los elementos exóticos que podían dar vistosidad a la ación: "La escena representa un magnífico salón adornado a la chinesca. Por un lado se verá el cuarto del emperador; por otro, el de Viting. Tiene otras puertas para el resto del palacio. En el frente la entrada a la torre o prisión de los reos de Estado. A un lado un tribunal, a otro el trono imperial". Aun cuando en la censura se insiste en que en la tragedia se da un pésimo ejemplo al pueblo, pues "en ella se trama una rebelión contra el rey, se asalta su palacio y se asesina al heredero", los censores no pasaron por alto el lado oriental de la obra, y así dicen: "La afectación de usar voces chinas en donde debieran servirse de las equivalentes castellanas y las alusiones frecuentes a los ritos y sucesos de aquel país hacen oscuro el sentido, especialmente para los que carecen de aquella noticia" (véase Aguilar Piñal 1987, págs. 184-186).

Pertenece también al ámbito oriental la tragedia Solaya o los circasianos de José Cadalso. Escrita probablemente hacia 1770, fue rechazada por los censores y no llegó a representarse ni a ser publicada. Su texto ha permanecido desconocido hasta su hallazgo y publicación reciente ${ }^{19}$. La acción de la pieza transcurre en Circasia, en el Cáucaso, en la época de Tamerlán: es la historia del amor imposible entre Solaya, noble circasiana, y Selim, embajador e hijo del kan de Tartaria, tirano de Circasia. La lucha entre el amor, el honor y el patriotismo se saldará con la muerte del joven tártaro. A diferencia del Viting, en esta tragedia apenas hay indicaciones escenográficas y el color local aparece reducido a su mínima expresión.

La acción de otras tragedias originales españolas transcurre en el norte de África ${ }^{20}$. Así, la Zafira (1787, impresa en Barcelona, Vda. Piferrer, s.a.) de Luis Repiso, escenifica la intervención española en Argel a principios del siglo XVI contra el tirano Aruch Barbarroja, mezclando en el asunto una historia de amor no correspondido entre el tirano y Zafira, madre del rey de Tremecén. Se exalta en la pieza el valor de los españoles, que aparecen como libertadores del pueblo y destructores de la tiranía. Del mismo año, Brahem ben Alí (Alcalá, P. López, 1787) de Manuel Amigó, que usó el seudónimo de José Milanés, presenta la historia de un sultán de Marruecos del siglo XIII, que debe enfrentarse a la sublevación de un jefe bereber. A los últimos años del siglo pertenece la tragedia de José Villaverde Zorayda, reina de Túnez (Alcalá, I. López, 1793).

19. Por F. Aguilar Piñal, Madrid, Castalia, 1982.

20. Existe precisa y abundante información sobre estas obras en Mendoza 1979; el mismo autor ha tratado aspectos parciales en Mendoza 1981 y en Mendoza 1988. Véanse también las páginas dedicadas al género por Palacios 1988. 
En Turquía está ambientada la comedia El gran visir otomano (1789, inédita), atribuida recientemente a José Concha (véase Santoro 1988), con intriga complicada, golpes de efecto, puesta en escena espectacular (batallas, desfiles). La escenografía está también muy cuidada en Alí-Bek (Madrid, B. García, 1801) de Rosa María Gálvez: "La escena es en las alturas de Saldeik, en el interior de la tienda de Mahomad, magníficamente adornada al uso oriental. Habrá hacia el foro una mesa al gusto asiático y varios almohadones para sentarse". La pieza tiene por asunto la conjura urdida por el rebelde Mahomad contra el rey de Egipto, en la que intervienen también el amor y la religión, pues la esposa de Alí-Bek es cristiana. Más al este se sitúa la acción de Gombela y Suni-Ada (Madrid, B. García, 1800) de Juan Francisco del Plano: desposeída del trono de Ceilán, Gombela lucha, con la ayuda de su enamorado Suni-Ada, para vengar la muerte de sus tres hermanos y expulsar al tirano usurpador.

Grupo aparte, por lo dicho al principio, lo forman las tragedias que escenifican episodios de la Reconquista. En algunos casos se han dado curiosas coincidencias. Así, El Pelayo (1769, impreso en Madrid, s.i., 1792) de Jovellanos (conocida también por Munuza), la Hormesinda (Madrid, P. Aznar, 1770) de Nicolás Fernández de Moratín y el Pelayo (Madrid, García y Cía., 1805) de Quintana se basan en los supuestos amores de Hormesinda, hermana de D. Pelayo, con Munuza, gobernador árabe de Gijón. También coinciden en el tema Don Sancho García (Madrid, Ibarra, 1771) de Cadalso y La condesa de Castilla (1798, impresa en Valencia, I. Mompié, 1815) de Âlvarez Cienfuegos: los amores de Almanzor con la condesa Ava, madre de Sancho, y las implicaciones políticas de los mismos. Pueden señalarse asimismo Guzmán el Bueno (Madrid, A. de Sancha, 1777), tragedia de Nicolás Fernández de Moratín, y el soliloquio homónimo con intervalos musicales de Tomás de Iriarte (1789, impreso en Cádiz, Ximénez Carreño, 1790). Algo al margen quedaría la Zoraida (1798, impresa en Valencia, I. Mompié, 1815) de Cienfuegos, sobre los amores de una dama de la corte de Boabdil con Abenamet, abencerraje preso, que terminarán con la muerte de ambos ordenada por el rey.

Y lo dicho para estas obras es de aplicación a las piezas, normalmente tragedias, relativas a la conquista y colonización de la América española: el Motezuma (Madrid, J. Ibarra, 1784) de Bernardo María de Calzada, si no elogiosa por lo menos en absoluto crítica respecto de la intervención española; o el Atuhualpa (Madrid, A. de Sancha, 1784) de Cristóbal María Cortés, que refleja las luchas por el poder entre los incas Huascar y Atahualpa, con la aparición de Pizarro que ofrece la protección del rey de España. Otras tragedias fueron traducciones: el mejor ejemplo es el de Alzira de Voltaire, traducida entre otros por el mencionado Calzada.

Durante el siglo XVIII las tragedias de asunto oriental o americano partían de un hecho histórico, aunque matizado o alterado por el autor. Dice María Rosa Gálvez en el prólogo a su Ali-Bek: 
La presente tragedia es enteramente original. Su acción está sacada de la historia de Egipto y de la rebelión, sorpresa y muerte de Alí-Bek, acaecida en aquel país a mediados del siglo último. Lo estéril del asunto y el poco interés que podía causar su representación si nada se hubiese añadido a los hechos históricos han movido a la autora a inventar algunos.

Al mantenimiento del interés de los espectadores ayudó, además de la complicación de la intriga, la fastuosidad y el propio exotismo de los decorados. Así, en una de las versiones de Alzira, titulada La Elmira, la pomposa escenificación se opone totalmente a la sencillez de la tragedia volteriana, la acción de la cual transcurre por entero en la sala de un palacio. Ahora, en el primer acto el escenario debe representar una "campiña dilatada y frondosa con varios cocos, palmas y otros frutales silvestres esparcidos en lo más retirado del foro", mientras que en el cuarto, cuando va a celebrarse una boda, debe aparecer "un atrio espacioso de un templo con su fachada al frente y puerta usual en ella. Soldados españoles sobre las armas hacia alrededor, al tiempo que salen tropas de doncellas españolas e indias damas de Elmira, Álvaro Guzmán, Mozoco, Tello y Elmira con guirnaldas de mirto y jazmín en la cabeza. La guardia del gobernador cierra la comitiva"21.

No menos espectaculares debían resultar los bailes, en cuya organización destacó el coreógrafo italiano afincado en Madrid Domingo Rossi: a él se deben títulos como La victoria de Tamerlán sobre Bayaceto, La Alzira, o El primer día del año en China o sea el matrimonio que en este día contrae el emperador, a que comúnmente llaman la fiesta de la linterna.

Los primeros años del siglo XIX presenciaron la aparición de distintos dramas y tragedias que, por la fuerza de las pasiones que pintaban parecían señalar una nueva época: del duque de Rivas, por ejemplo, Aliatar (Sevilla, Cano, 1816) y Malek-Adhel (1818, impresa en Madrid, Sancha, 1820), historias de amores imposibles entre musulmanes y cristianas, adaptación el segundo de la novela de Mme Cottin Mathilde; de Martínez de la Rosa Morayma (1818, impresa en París, 1829), episodio de las guerras civiles de Granada.

También fue una época de triunfo del melodrama, género que unía a una intriga complicada y patética una escenografía aparatosa. La mayoría de los melodramas que se representaron en España son traducciones del francés, a veces a partir de un original alemán (de Kotzebue): Tipoo-Saib o La toma de Seringapatán, El poder de la inocencia o Los moros de Granada, Los inquilinos de Sir John o La familia de la India, Aradín Barbarroja, El mágico y el cestero o El diablo verde (interesante por la aparición de la magia).

21. Véanse Elmira o la Americana. Valencia, Domingo y Mompié, 1820. 
Algunas - pocas - presencias de lo exótico en poesía se hallan en tipos muy distintos de composiciones poéticas ${ }^{22}$. En la poesía épica hallamos una Muerte de Barbarroja, poema en octavas de Ignacio Merás (Madrid, B. Cano, 1797). La poesía erótica parecía de entrada idónea para dar cabida a la sensualidad o, mejor, a la lascivia oriental. Pocas son, sin embargo, las composiciones del Jardín de Venus de Samaniego con protagonistas no europeos: los negros africanos de El país de afloja y aprieta, el turco de El piñón y los árabes de La peregrinación (véase Samaniego, 1976).

Más abundante es la poesía amatoria, muy sensual a veces, como la que se encuentra en el libro Poesías asiáticas del Conde de Noroña, publicado en París en 1833 (Didot), aunque escrito mucho antes, pues el autor había muerto en 1815 . Se trata de un conjunto de 128 poemas traducidos del inglés, de muy distinto cariz, acompañados de abundantes notas: la mayoría son árabes, salvo 26 poemas persas y 2 turcos. Parece que las recopilaciones de donde los tomó el conde fueron Poeseos asiaticae commentarii (1774) de William Jones, Specimens of Arabian Poetry (1796) de Joseph Dacre Carlyle y The Flowers of Persian Literature (1801) de Samuel Rousseau (véase Fitzmaurice-Kelly, 1908). Como presintiendo el lugar que iba a ocupar la poesía árabe en la renovación del gusto occidental escribe el autor estas palabras en su advertencia:

Me prometo que los amantes de la verdadera poesía distinguirán estas composiciones llenas de fuego e imágenes pintorescas, de las insulsas filosóficas prosas rimadas que nos han venido de algún tiempo acá de allende de los Pirineos, vendiéndonoslas como buena mercancía. Los genios españoles, que tanto han brillado por su fecunda y hermosa imaginación, deben abandonar esas gálicas frialdades y no desdeñarse de leer los poetas del Oriente, en quienes todo es calor y entusiasmo, y entre los cuales suenan con honor algunos hispanos, cuyas obras yacen sepultadas en el Escorial (Véase AA.VV. 1952, pág. 471).

Quisiera, para terminar, traer a colación una palabras de Domingo Badía o, si se prefiere, Alí Bey, que expresan el rechazo de la sociedad mercantilista o industrial - moderna-, contraponiéndola a unas formas de vida más libres y auténticas, que en su tiempo podían hallarse todavía en los países que visitó en su recorrido africano y asiático:

Lo confesaré, ya que lo he experimentado: al entrar en estos países [europeos] circunscritos por la propiedad individual el corazón del hombre se encoge y comprime. No vuelvo los ojos, no puedo dar un paso sin tropezar con un seto que parece me diga: "Alto ahí, no traspases este límite". Mi corazón se desanima, mis fibras se relajan, me abandono muellemente al movimiento de mi caballo y me parece no ser ya el mismo Alí Bey, aquel árabe que, lleno de energía y fuego, se lanzó en medio de los desiertos de

22. No he tomado en consideración algunos romances moriscos, hechos a imitación de un tipo de poesía cultivado en el Siglo de Oro; tal vez el ejemplo más conocido sea el de Los bereberes de V. García de la Huerta. 
África y Arabia, como el atrevido navegante que se abandona a las olas de un mar tempestuoso con la fibra siempre en tensión y el espíritu preparado a todo evento. No hay duda que es un grande bien la sociedad; que la mayor dicha del hombre consiste en vivir bajo un gobierno bien organizado que, con el sabio empleo de la fuerza pública, asegura a cada individuo la posesión pacífica de su propiedad; mas también me parece que cuanto se gana en seguridad y tranquilidad se pierde en energía (Véase Badía 1986, II, pág. 397).

Poco comentario necesitan tales consideraciones. En cualquier caso, el espíritu que las sustenta es muy distinto del puramente curioso, basado en el ansia de conocimiento y en la difusión del mismo, que animaba a los viajeros del XVIII. Precisamente la inflexión que puede apreciarse en este texto es la señal de un cambio de mentalidad y de gusto que caracteriza el paso del XVIII al XIX.

\section{REFERENCIAS BIBLIOGRÁFICAS}

AA.VV. 1952. Poetas líricos del siglo XVIII, ed. L.A. CUETO Madrid, Atlas, vol. II (BAE LXIII).

- 1989. España y el mar en el siglo de Carlos III, Madrid, Marinvest.

AGUILAR PIÑAL, Francisco. 1981 y ss. Bibliografia de autores españoles del siglo XVIII, Madrid, CSIC.

- 1987. Un escritor ilustrado: Cándido María Trigueros, Madrid, CSIC.

- 1988. Bibliografía de estudios sobre Carlos III y su época, Madrid, CSIC.

ÁLVAREZ BARRIENTOS, Joaquín. 1991. La novela del siglo XVIII, Madrid, Júcar (dentro de la Historia de la literatura española de R. de la Fuente).

BADÍA, Domingo (Alí Bey). 1986. Viajes por Marruecos, Trípoli, Grecia y Egipto, prólogo de Juan GOYTISOLO, Barcelona, José Olañeta, 2 vols.

BRAVO MORATA, Federico. 1972. Carlos III y su tiempo, Madrid, Fenicia.

BREMER, Klaus-Jürgen. 1971. Montesquieus "Lettres persanes" und Cadalsos "Cartas marruecas", Heidelberg, Carl Winter.

CADALSO, José. 1966. Cartas marruecas, ed. Lucien DUPUIS y Nigel GLENDINNING, Londres Tamesis Books.

CARNERO, Guillermo. 1988. "Sensibilidad y exotismo en un novelista entre dos siglos: Gaspar Zavala y Zamora" en Romanticismo 3-4. Atti del IV Congreso sul Romanticismo spagnolo, Bordighera, 1987, Génova, Universidad, pp. 23-29.

- (ed.). 1992. Gaspar ZAVALA y ZAMORA. Obra narrativa: La EumeniaOderay, Barcelona, Sirmio \& Universidad de Alicante. 
COTARELO Y MORI, Emilio. 1897. Iriarte y su época, Madrid, Sucesores de Rivadeneyra.

COTTON, Emily. 1931. "Cadalso and his Foreign Sources", Bulletin of Spanish Studies VIII, pp. 5-18.

CRUZ, Ramón de la. 1915. Sainetes, ed. Emilio COTARELO, Madrid, Bailly-Baillere, vol. II (NBAE, 23).

DEACON, Philip. 1981. "Las perdidas Cartas turcas de Meléndez Valés", Bulletin Hispanique LXXXIII, pp. 447-462.

DEFOURNEAUX, Marcelin. 1973. Inquisición y censura de libros en la España del siglo XVIII, Madrid, Taurus.

ESCOBAR, José y Anthony PERCIVAL. 1984. "Viaje imaginario y sátira de costumbres en la España del siglo XVIII: los Viajes de E. Wanton al país de las monas" en Aufstieg und Krise der Vernunft, Viena, Hermann Böhlaus Nachf, pp. 79-94.

FERNÁNDEZ CARDO, José M"a . 1989. "La otra cultura en esta literatura: funciones exóticas de la escritura" en F. LAFARGA (ed.), Imágenes de Francia en las letras hispánicas, Barcelona, PPU, pp. 371-378.

FERNÁNDEZ MONTESINOS, José. 1966. Introducción a una historia de la novela en España en el siglo XIX, Madrid, Castalia.

FITZMAURICE-KELLY, James. 1908. "Noroña's Poesía asiáticas", Revue Hispanique 18, pp. 439-467.

GUINARD, Paul J. 1958. "Une adaptation espagnole de Zadig au XVIIIe siècle" Revue de littérature comparée 32, pp. 481-495.

HUGUES, John B. 1969. José Cadalso y las "Cartas marruecas", Madrid, Tecnos.

IGLESIAS, Nieves y Ana M MAÑÁ. 1968. Correo de Madrid o de los Ciegos, Madrid, Hemoroteca Municipal.

JOURDA, Pierre. 1938. L'exotisme dans la littérature française depuis Chateaubriand, reimpr. Ginebra, Slatkine, 1970.

LABORDE, Paul. 1952. "Cadalso et Montesquieu" Revue des langues romanes LXXI, pp. 171-180.

LAFARGA, Francisco. 1977. "Sobre la fuente desconocida de Zara, sainete de R. de la Cruz" Anuario de Filología 3, pp. 361-371.

- 1982. Voltaire en España, 1734-1835, Barcelona, Universidad.

- 1989. Voltaire en Espagne (1734-1835), Oxford, The Voltaire Foundation (Studies on Voltaire, 261).

MENDOZA FILLOLA, Antonio. 1979. La tragedia neoclásica española, 17101819, Universidad de Barcelona (tesis doctoral inédita). 
- 1981. "Aspectos de la tragedia neoclásica española" Anuario de Filología 7, pp. 369-389.

- 1988. "El compromiso colonial y el despotismo en la tragedia neoclásica" en Coloquio internacional sobre el teatro español del siglo XVIII. Bolonia, octubre de 1985, Abano Terme, Piovan, pp. 267-287.

SAMANIEGO, Félix. 1976. El jardín de Venus, ed. Emilio PALACIOS, Madrid, Siro.

SANTORO, Paola. 1988. "II Gran Visir otomano ritrova il suo autore" Nuovi Annali della Facoltà di Magistero dell' Università di Messina 6, pp. 723-734.

VARELA, Eulogio. 1966. El Espíritu de los mejores diarios, Madrid, Hemeroteca Municipal. 